\title{
Vicious circle in the intertidal: Facilitation between barnacle epibionts, a shell boring polychaete and trematode parasites in the periwinkle Littorina littorea
}

\author{
David W. Thieltges *, Christian Buschbaum \\ Alfred Wegener Institute for Polar and Marine Research, Wadden Sea Station Sylt, Hafenstrasse 43, 25992 List, Germany
}

Received 5 January 2006; received in revised form 15 March 2006; accepted 22 August 2006

\begin{abstract}
We studied interactions between three organisms associated with a common gastropod of northern Atlantic shores, the periwinkle Littorina littorea: barnacle epibionts Balanus crenatus, a shell boring polychaete Polydora ciliata, and tissue invading trematodes which use the periwinkles as first intermediate host. Snails collected shortly after barnacle settlement with $>50 \%$ cover of barnacles had significantly higher infestation of shell boring worms compared to unfouled snails, while trematode infestation was similar. The result was the same at two sites, and we conclude that the worm P. ciliata facilitates barnacle fouling on snails. The reverse was also the case. In an experiment with 14 weeks of exposure, snail treatments with barnacle epibionts had a significantly higher $P$. ciliata load than unfouled and cleaned snails. Again, trematode infestations were similar. The reciprocal positive interactions between barnacle epibionts and shell boring worms on snail houses is regarded as a case of facultative mutualism. On the other hand, for the snail basibiont, both barnacles and shell boring worms exert strongly negative effects by reducing fecundity, growth, and survival, resulting in a vicious circle for the snails. The combined effects of these associated organisms may rival in importance any competitive or predacious effects on the host L. littorea.
\end{abstract}

(C) 2006 Elsevier B.V. All rights reserved.

Keywords: Basibiont; Epibionts; Epibiosis; Periwinkle; Trematode

\section{Introduction}

Epibiosis, i.e. species serving as substrate (basibiont) for other organisms (epibionts), is a common phenomenon and an important ecological issue in marine systems (Wahl, 1989). In molluscs and especially in gastropods, epibionts like barnacles have been described to exert multiple negative effects on their basibionts such as enhanced dislodgment by increased drag forces, shell destruction, reduced mobility, lower fecundity or even mortality

\footnotetext{
* Corresponding author. Tel.: +49 4651956 0; fax: +49 4651956200

E-mail address: dthieltges@awi-bremerhaven.de(D.W. Thieltges).
}

(Witman and Suchanek, 1984; Wahl, 1996, 1997; Buschbaum and Reise, 1999; Buschbaum and Saier, 2001).

Epibionts are not the only organisms associated with molluscs (Cheng, 1970; Lauckner, 1980, 1983). Shell boring polychaetes seek shelter in the calcareous substrate. Tissues of molluscs are often inhabited by parasitic trematodes utilizing molluscs as first intermediate hosts in their complex life cycles. These shell boring polychaetes and tissue inhabiting trematodes might interact with epibionts with the outcome being negative, neutral or positive.

In this study we investigated reciprocal effects of shell boring polychaetes and tissue inhabiting trematodes on 
barnacle epibionts and used the periwinkle Littorina littorea as a model host. L. littorea is one of the most common gastropods at North Atlantic shores (Bertness, 1999) with a diverse epibiont community (Wahl and Hay, 1995; Buschbaum and Reise, 1999). In our study area, epibionts of $L$. littorea are mainly barnacles with up to $70 \%$ of snails on lower intertidal mussel beds being strongly covered with barnacles (Buschbaum and Reise, 1999). Besides barnacles, the shell boring polychaete Polydora ciliata and six species of tissue inhabiting trematodes utilising the snail as first intermediate host are commonly associated with L. littorea (Dorsett, 1961; Werding, 1969; Lauckner, 1980; Warner, 1997).

It is likely that positive interactions occur between shell boring polychaetes or tissue inhabiting trematodes and barnacle epibionts. The holes excavated by $P$. ciliata might attract rough surface preferring barnacle larvae during settlement resulting in enhanced densities of barnacle epibionts. Barnacle epibionts on the other hand might enhance settlement by $P$. ciliata by providing rough surfaces resulting in higher infestation rates of this species. Trematodes might weaken the snail's natural defences (organic coating on shell surface, chemical defences etc.) against epibionts resulting in higher barnacle cover on infected snails. Barnacle cover on the other hand might attract trematode infective stages due to chemical cues or make snails more susceptible to trematode infections by weakening the snail's natural defences. In contrast, negative interactions are also likely: P. ciliata worms might push off barnacle larvae from the shells at settlement resulting in inhibition of barnacle epibionts. On the other hand, barnacle epibionts may prey on or otherwise prevent P. ciliata larvae from settling inhibiting worm infestation. Trematodes might make snails less attractive to barnacle epibionts resulting in a lower barnacle coverage. Barnacle epibionts on the other hand, may negatively affect trematodes by preying upon trematode larvae intending to infest the snail.

We tested four null hypotheses regarding potential interactions between barnacle epibionts and infestation by P. ciliata or trematode parasites: 1 ) infestation by the shell boring polychaete $P$. ciliata does not affect the settlement of barnacles, 2) tissue inhabiting trematodes do not affect the settlement of barnacle epibionts, 3) barnacle epibionts do not affect the infection of snails by the shell boring P. polydora and 4) barnacle epibionts do not affect the infection of snails by tissue inhabiting trematodes. In the case that a null hypothesis is rejected, the interaction may be positive (facilitation) or negative (inhibition). To test hypotheses 1) and 2), we sampled and investigated snails with and without juvenile barnacle epibionts shortly after barnacle settlement. To test hypothesis 3 ) and 4), we experimentally exposed snails that were barnacle-fouled, unfouled and cleaned (from barnacle cover) in the field for 14 weeks.

\section{Materials and methods}

\subsection{Study area}

Investigations were carried out in the northern Wadden Sea near the island of Sylt (North Sea, Germany) (Fig. 1). Tides are semidiurnal with a mean range of $2 \mathrm{~m}$. Salinity remains close to $30 \mathrm{psu}$. Mussel beds (Mytilus edulis) cover about $3 \%$ in the intertidal zone and are the most favourable habitat for periwinkles $L$. littorea where they can reach densities of $>2000$ ind. $\mathrm{m}^{-2}$ (Buschbaum, 2000). For further information on the area see Gätje and Reise (1998).

\subsection{Field survey}

To investigate effects of shell boring $P$. ciliata and tissue inhabiting trematode presence on barnacle epibiont

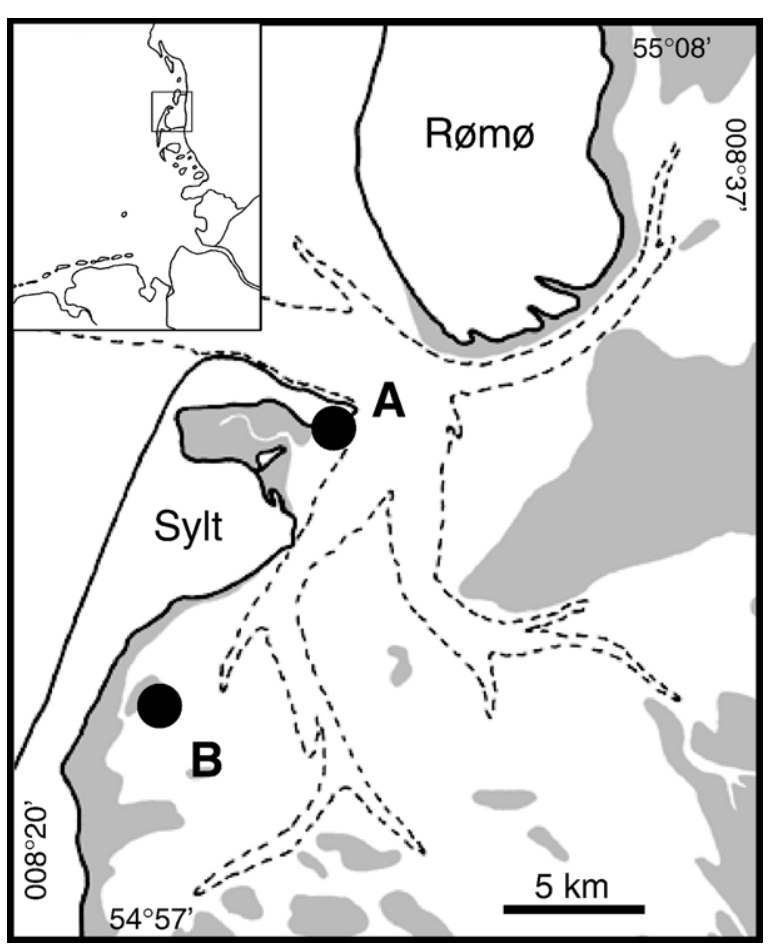

Fig. 1. Study area, the List tidal basin (North Sea, Germany). Black dots indicate mussel beds where investigations were carried out. Site A is located near the northern tip of the island of Sylt while site B is located in the inner part of the bight. Shaded areas indicate the intertidal. 
settlement (hypotheses 1 and 2) we collected L. littorea from two mussel beds following the barnacle settlement period in May 2003 (Fig. 1). On each mussel bed, an unbiased sample of 100 individuals completely unfouled and 100 individuals fouled by barnacles (Balanus crenatus) with $>50 \%$ shell coverage (Fig. 2 ) was obtained by repeatedly and randomly throwing a $1 / 8-\mathrm{m}^{2}$-frame within an area of $20 \mathrm{~m}^{2}$ in the lower intertidal $(+50 \mathrm{~cm}$ mean low water level (MLWL) to MLWL) and collecting all snails with appropriate fouling and size. Snails fouled by early recruits of barnacles ( $<2 \mathrm{~mm}$ shell diameter) and no other epibionts were chosen to ensure that settlement had taken place within the preceding 2 weeks (Bertness, 1999). Since barnacles, P. ciliata and trematodes only occur in larger snails, individuals from 16 to $23 \mathrm{~mm}$ were collected. Snails $>23 \mathrm{~mm}$ were not found at the sites. In the laboratory, snail shell height was measured with a calliper to the nearest $0.1 \mathrm{~mm}$. After crushing the shell, body tissues and shells were investigated for P. ciliata and trematode (sporocysts/rediae) presence under a dissection microscope.

\subsection{Field experiment}

To examine potential effects of barnacle epibionts on infestation by $P$. ciliata and trematodes (hypotheses 3 and 4) a field experiment was conducted on mussel bed A (Fig. 1). Fouled (with one year old B. crenatus $>70 \%$ shell coverage) and unfouled snails of 16-20 mm were collected randomly within the same area of the mussel bed. Before the experiment, 100 fouled and unfouled snails were investigated for $P$. ciliata and trematode prevalence to estimate a baseline for infection levels. Barnacle cover on 120 fouled snails was carefully removed with a knife allowing us to create three treatments: 1) snails with barnacle epibionts ("fouled"), 2)

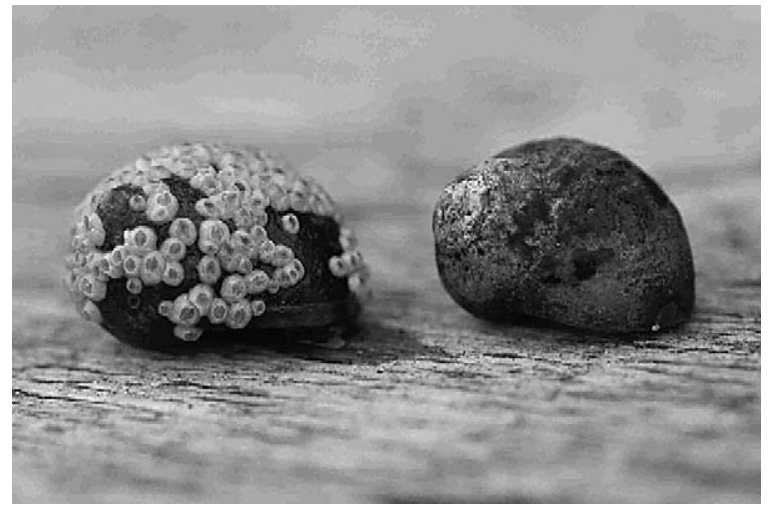

Fig. 2. Periwinkles (L. littorea) with (left) and without (right) barnacle epibionts shortly after barnacle settlement used for investigations.

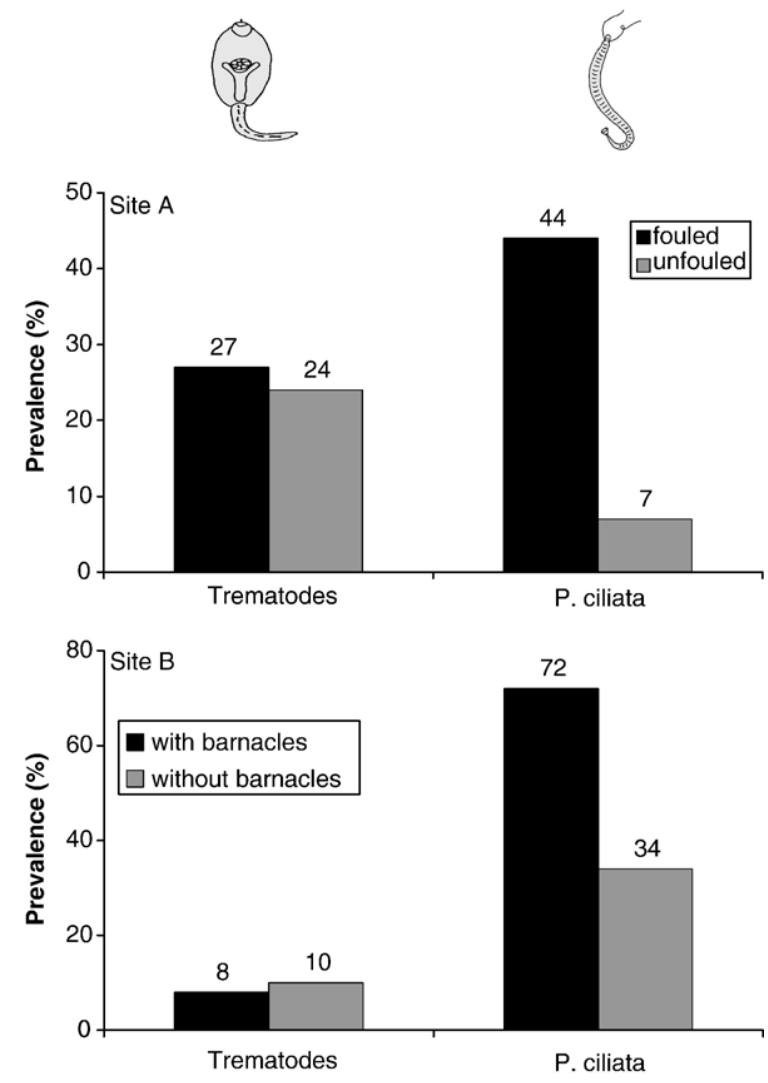

Fig. 3. Prevalence (\%) of trematodes and P. ciliata in barnacle fouled and unfouled L. littorea on two mussel beds (Mytilus edulis). $n=100$ each.

snails with barnacle epibionts removed ("cleaned snails") and 3) snails without any natural epibionts ("unfouled"). 20 individuals of each treatment were put in a cage made of polyethylene ( $5 \mathrm{~mm}$ mesh size) of $25 \mathrm{~cm}$ diameter and $30 \mathrm{~cm}$ height together with blue mussels (M. edulis) of natural density. Cages were fixed with iron rods on the mussel bed in June 2003 in a completely random design near low water line. All three treatments were replicated six times. After 14 weeks of exposure the cages were emptied and snails investigated for $P$. ciliata and trematodes as described above.

\subsection{Statistical analysis}

Statistical analysis for differences in prevalence (\% infected from total sample) of $P$. ciliata and trematodes between barnacle fouled and unfouled snails was performed using Chi-square tests $(2 \times 2$ frequency tables $)$. The field experiment was analysed using analysis of variance (one-way ANOVA). Post hoc calculations were carried out with Tukey HSD-test (Day and Quinn, 1989). Since Cochran's- $C$-Test showed homogeneous 
variances and data were normally distributed, nontransformed data were used for the analysis. Shell height of snails was compared between treatments using $t$-tests (field study) or one-way ANOVA (field experiment) following log-transformation of data to result in homogeneity of variance and normal distribution.

\section{Results}

Shortly after barnacle settlement, fouled L. littorea were found to be significantly more infested by $P$. ciliata than unfouled snails (Chi-square test, $p<0.001$ for each mussel bed; Fig. 3). This was due to a $2-6$ times higher infestation in fouled compared to unfouled snails. Significant differences in infestation by trematodes between barnacle fouled and unfouled snails were not detected at either site (Chi-square test, $p=0.6$ for each mussel bed). There were no significant differences in snail shell height between fouled and unfouled snails at the two sites $\left(t\right.$-tests, $F_{\text {Site A }}=1.08, p_{\text {Site A }}=0.30 ; F_{\text {Site B }}=0.53$, $\left.p_{\text {Site } \mathrm{B}}=0.47\right)$. Parasites found in the snails were Renicola roscovita, Cryptocotyle lingua, Himasthla elongata, Microphallus pygmaeus and Podocotyle atomon.

In the cage experiment significant differences in $P$. ciliata prevalence were observed between the three treatments (one-way ANOVA, $F_{2,15}=38.30, p<0.001$; Fig. 4). This was due to a 2-7 times higher prevalence of P. ciliata in fouled $(51.2 \pm 5.7 \%)$ compared to cleaned $(24.7 \pm 3.2 \%)$ and unfouled $(7.8 \pm 3.5 \%)$ L. littorina (Tukey-HSD: fouled-cleaned: $<0.001$; fouled-unfouled: $<0.001$; cleaned-unfouled: $<0.01)$. No statistical difference was observed in trematode prevalence (fouled: $12.4 \pm 2.2 \%$; cleaned: $10.2 \pm 3.7 \%$; unfouled: $7.8 \pm 3.5 \%$ ) (one way-ANOVA, $F_{2,15}=5.10, p=0.61$ ) and mortality (fouled: $6.3 \pm 1.7 \%$; cleaned: $1.7 \pm 1.1 \%$; unfouled: $2.7 \pm$ $1.8 \%$ ) (one way-ANOVA, $F_{2,15}=2.25, p=0.14$ ) of snails

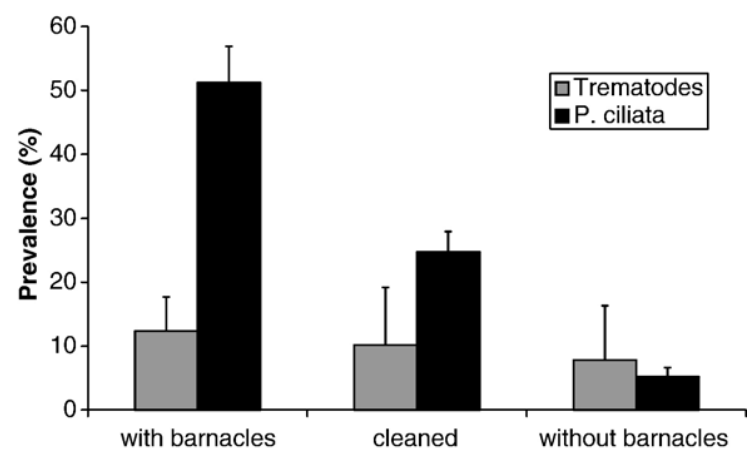

Fig. 4. Mean prevalence (\%) + SE of $P$. ciliata and trematodes in three experimental treatments of $L$. littorea. Fouled: Naturally barnacle fouled snails; cleaned: fouled snails with barnacle epibionts taken off; unfouled: naturally unfouled snails. $n=6$ for each treatment. between the three treatments. There was no significant difference in snail shell height between the three treatments (one way ANOVA, $F_{2,357}=1.34, p=0.25$ ). Trematodes found in snails were as above. At the beginning of the experiment, $P$. ciliata and trematode prevalence in fouled snails was $20 \%$ and $11 \%$, respectively (unfouled snails: $8 \%$ and $9 \%$ ).

\section{Discussion}

Our results demonstrate that barnacle epibionts and shell boring $P$. ciliata strongly facilitate each other while tissue inhabiting trematodes do not seem to interact with barnacle epibionts in L. littorea.

Infestation by $P$. ciliata facilitates the settlement of barnacles on L. littorea. Shortly after barnacle settlement, snails with barnacle epibionts present showed a higher infestation by P. ciliata than individuals without epibionts. Since only 2 weeks had passed between barnacle settlement and our investigation, the observed effects are due to the presence of $P$. ciliata before and not following the settlement of barnacles inferred from the mostly adult sizes of the spionid worms. Although not a controlled experiment, a facilitative process is likely: barnacle larvae are known to be attracted by rough, uneven surface textures at settlement (e.g. Crisp and Barnes, 1954) here provided by the holes and crevices created by $P$. ciliata. Larger barnacle epibionts were also found to be correlated with $P$. ciliata presence (Warner, 1997). However, Warner (1997) suggested this to result from barnacles facilitating $P$. ciliata settlement and not the other way round.

Trematode infestations did not correlate with barnacle settlement. We predicted that trematodes might weaken potential antifouling mechanisms of snails by interfering with the snail's metabolism resulting in a higher degree of fouling in trematode infected individuals. However, it is suspected that L. littorea has a lack of specific antifouling capacities (Wahl and Sönnichsen, 1992). This might explain our finding since there may not be a mechanism that can be influenced by trematode infestations.

Barnacle epibionts facilitate infestation of snails by $P$. ciliata. After 14 weeks of exposure, snails with barnacle epibionts showed higher $P$. ciliata prevalence than con-specifics without epibionts. P. ciliata larvae are known to settle preferentially on uneven surfaces and scratches (Daro and Polk, 1973) and hence the crevices between the base of the barnacle shells and the snail shell surface may have made entering the gastropod shell easier for the polychaete. Indeed, direct observations confirmed that most $P$. ciliata holes occurred at the 


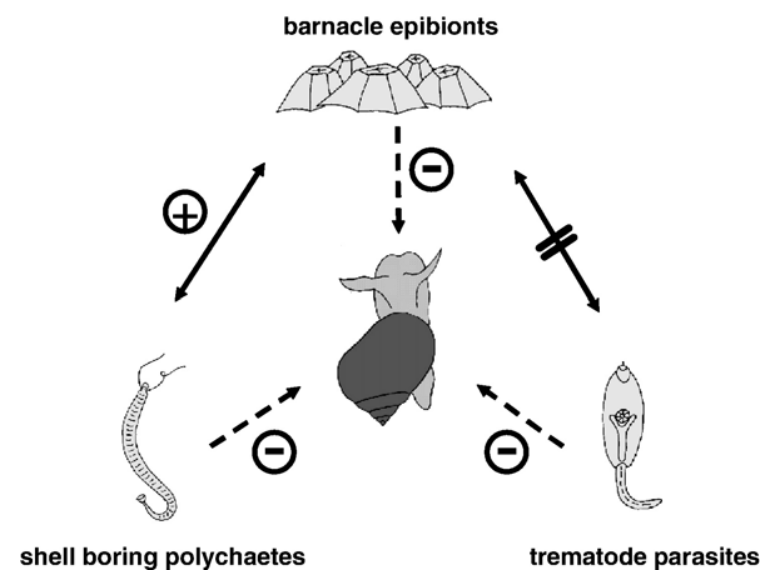

Fig. 5. Schematic illustration of the importance of facilitative processes in interactions between barnacle epibionts, shell boring polychaetes and trematode parasites. The facilitative interaction $(+)$ between barnacle epibionts and shell boring polychaetes leads to a vicious circle since both exert negative effects (-) on the gastropod basibiont.

base of barnacle cones. A rapid colonization of experimental snails is highly likely: Polydora larvae are locally present all over the summer (Rodríguez Valencia, 2003) and have been shown to colonize experimentally exposed substrates within weeks (Hempel, 1957, 1960; Daro and Polk, 1973). The prevalence of P. ciliata in cleaned snails and unfouled snails was similar to the preload of $P$. ciliata of fouled and unfouled snails at the start of the experiment ( $20 \%$ and $8 \%$, respectively). This indicates that no or only few additional infections occurred during the experiments in absence of barnacle epibionts. Hence, barnacle epibionts were responsible for the observed increase in P. ciliata infections.

Trematode prevalence was not affected by barnacle epibionts since there was no difference in prevalence in the three treatments after 14 weeks of exposure. Infective stages (miracidiae) are present all over the year due to high abundance of seabird final hosts with high trematode loads in the area (Thieltges, unpublished data). Development of rediae and sporocysts in digenean trematodes takes several weeks and infections can be identified by careful observation even in early premature stages (Lo, 1995; Ataev et al., 1997; Graczyk et al., 2000). Hence, the duration of the experiment should have been long enough to detect any potential changes but of course it cannot be excluded that parasite accumulation in long lived hosts occurs too slowly to be detected within 14 weeks (Curtis, 1996). However, if there were a slightly positive effect in the long run, this may not be ecologically significant. Hence, we conclude that barnacle epibionts had no or a very week effect on trematode prevalence.
Overall, the shell boring polychaete $P$. ciliata and barnacle epibionts strongly facilitate each other in L. littorea (Fig. 5). This reciprocal facilitation is an advantage for both species as they are provided with a better access to the substrate resource. This is an example of facultative mutualism (Stachowicz, 2001). $P$. ciliata and barnacle epibionts both exert strong negative effects on the basibiont $L$. littorea. Infestation by $P$. ciliata leads to a gradual destruction of the gastropod shell and a reduced resistance against shell breakage (Buschbaum et al., in press). This makes P. ciliata infested snails more vulnerable to predators like crabs (Buschbaum et al., in press) as has also been shown in $P$. ciliata infested bivalves (Ambariyanto and Seed, 1991). Barnacle epibionts have been shown to lower survival, growth and reproductive output in L. littorea (Wahl, 1996, 1997; Buschbaum and Reise, 1999). Considering these multiple negative effects, the observed facilitative process may be of high importance for L. littorea population dynamics. With $P$. ciliata and barnacle epibionts facilitating each other, interference competition with their snail hosts is strongly enhanced and results in a vicious circle for the snails. Hence, our findings are an example for a facilitative process ("+" interactions) between two associated organisms that results in strongly negative effects ("-" interactions) in the host (Fig. 5). In addition to single effects of epibionts (Buschbaum, 2000), predation (Rangeley and Thomas, 1987), competition (Fenske, 1997) and trematode infestations (Lambert and Farley, 1968; Lauckner, 1980; Huxham et al., 1993; Davies and Knowles, 2001), this study has shown that facilitative processes between epibionts and other snail associated organisms and concomitant indirect effects are also important biotic factors in L. littorea population dynamics.

\section{Acknowledgements}

We thank K. Reise and colleagues from the Wadden Sea Station writing week meeting for comments on the manuscript. Anonymous referees are thanked for their helpful comments on an earlier version of the manusucript. Allyson O'Brien is thanked for improving the English. [SS]

\section{References}

Ambariyanto, Seed, R., 1991. The infestation of Mytilus edulis Linneaus by Polydora ciliata (Johnston) in the Conwy estuary, North Wales. J. Molluscan Stud. 57, 413-424.

Ataev, G.L., Dobrovolskij, A.A., Fournier, A., Jourdane, J., 1997. Migration and development of the mother sporocysts of Echinostoma caproni (Digenea: Echinostomatidae). J. Parasitol. 83, 444-453. 
Bertness, M.D., 1999. The Ecology of Atlantic Shorelines. Sinauer Associates Inc., Sunderland.

Buschbaum, C., 2000. Direct and indirect effects of Littorina littorea (L.) on barnacles growing on mussel beds in the Wadden Sea. Hydrobiologia 440, 119-128.

Buschbaum, C., Reise, K., 1999. Effects of barnacle epibionts on the periwinkle Littorina littorea (L.). Helgol. Mar. Res. 53, 56-61.

Buschbaum, C., Saier, B., 2001. Growth of the mussel Mytilus edulis L. in the Wadden Sea affected by tidal emergence and barnacle epibionts. J. Sea Res. 45, 27-36.

Buschbaum, C., Schrey, I., Thieltges, D.W., in press. Shell boring polychaetes affect gastropod shell strength and crab predation. Mar. Ecol. Prog. Ser.

Cheng, T.C., 1970. Marine molluscs as hosts for symbioses — with a review of known parasites of commercially important species. Adv. Mar. Biol. 5, 1-424.

Crisp, D.J., Barnes, H., 1954. The orientation and distribution of barnacles at settlement with particular reference to surface contour. J. Anim. Ecol. 23, 142-162.

Curtis, L.A., 1996. The probability of a marine gastropod being infected by a trematode. J. Parasitol. 82, 830-833.

Daro, M., Polk, P., 1973. The autecology of Polydora ciliata along the Belgian coast. Neth. J. Sea Res. 6, 130-140.

Davies, M.S., Knowles, A.J., 2001. Effects of trematode parasitism on the behaviour and ecology of a common marine snail (Littorina littorea (L.)). J. Exp. Mar. Biol. Ecol. 260, 155-167.

Day, R.W., Quinn, G.P., 1989. Comparisons of treatments after an analysis of variance in ecology. Ecol. Monogr. 59, 433-463.

Dorsett, D., 1961. The behaviour of Polydora ciliata (Johnst.): Tubebuilding and burrowing. J. Mar. Biol. Assoc. UK 41, 577-590.

Fenske, C., 1997. The importance of intraspecific competition in a Littorina littorea population in the Wadden Sea. Hydrobiologia 355, 29-39.

Gätje, C., Reise, K. (Eds.), 1998. Ökosystem Wattenmeer, Austausch-, Transport- und Stoffumwandlungsprozessse. Springer, Berlin.

Graczyk, T.K., Alam, K., Gilman, R.H., Mondal, G., Ali, S., 2000. Development of Fasciolepsis buski (Trematoda: Fasciolidae) in Hippeutis umbilicalis and Segmentina trochideus (Gastropoda: Pulmonata). Parasitol. Res. 86, 324-326.

Hempel, C., 1957. Zur Ökologie einiger Spioniden (Polychaeta sedentaria) der deutschen Küsten. Kiel. Meeresforsch. 13, 275-288.

Hempel, C., 1960. Über das Festsetzen der Larven und die Bohrtätigkeit der Jugendstadien von Polydora ciliata (Polychaeta sedentaria). Helgol. Wiss. Meeresunters. 7, 80-92.

Huxham, M., Raffaelli, D., Pike, A., 1993. The influence of Cryptocotyle lingua (Digenae: Plathelminthes) infections on the survival and fecundity of Littorina littorea (Gastropoda: Prosobranchia). J. Exp. Mar. Biol. Ecol. 168, 223-238.

Lambert, T.C., Farley, J., 1968. The effect of parasitism by the trematode Cryptocotyle lingua (Creplin) on zonation and winter migration of the common periwinkle, Littorina littorea (L.). Can. J. Zool. 46, 1139-1147.

Lauckner, G., 1980. Diseases of Mollusca: Gastropoda. In: Kinne, O. (Ed.), Diseases of Marine Animals Vol. I, General Aspects, Protozoa to Gastropoda. John Wiley \& Sons, New York, pp. 311-424.

Lauckner, G., 1983. Diseases of mollusca: bivalvia. In: Kinne, O. (Ed.), Diseases of Marine Animals Vol. 2, Introduction, Bivalvia to Scaphopoda. Biologische Anstalt Helgoland, Hamburg, pp. 477-961.

Lo, C.T., 1995. Echinostoma marorchis: life history, population dynamics of intramolluscan stages, and the first and second intermediate hosts. J. Parasitol. 81, 569-576.

Rangeley, R.W., Thomas, M.L.H., 1987. Predatory behaviour of juvenile shore crab Carcinus maenas. J. Exp. Mar. Biol. Ecol. 108, 191-197.

Rodríguez Valencia, J.A., 2003. Composition and dynamics in space and time of polychaete larvae in coastal waters of the North Sea. $\mathrm{PhD}$ thesis, University Kiel.

Stachowicz, J., 2001. Mutualism, facilitation, and the structure of ecological communities. BioScience 51, 235-246.

Wahl, M., 1989. Marine ebibiosis. I. Fouling and antifouling: some basic aspects. Mar. Ecol. Prog. Ser. 58, 175-189.

Wahl, M., 1996. Fouled snails in flow: potential of epibionts on Littorina littorea to increase drag and reduce snail growth rates. Mar. Ecol. Prog. Ser. 138, 157-168.

Wahl, M., 1997. Increased drag reduces growth of snails: comparison of flume and in situ experiments. Mar. Ecol. Prog. Ser. 151, 291-293.

Wahl, M., Hay, M., 1995. Associated resistance and shared doom: effects of epibiosis on herbivory. Oecologia 102, 329-340.

Wahl, M., Sönnichsen, H., 1992. Marine epibiosis. IV. The periwinkle Littorina littorea lacks typical antifouling defences — why are some populations so little fouled? Mar. Ecol. Prog. Ser. 88, 225-235.

Warner, G.F., 1997. Occurrence of epifauna on the periwinkle, Littorina littorea (L.), and interactions with the polychaete Polydora ciliata (Johnston). Hydrobiologia 355, 41-47.

Werding, B., 1969. Morphologie, Entwicklung und Ökologie digener Trematoden-Larven der Strandschnecke Littorina littorea. Mar. Biol. 3, 306-333.

Witman, J.D., Suchanek, T.H., 1984. Mussels in flow: drag and dislodgement by epizoans. Mar. Ecol. Prog. Ser. 16, 259-268. 